\title{
Plant available moisture content in soils of Belarus under the current conditions
}

\author{
Aleksandr A. Volchak ${ }^{1}$, Ivan Kirvel ${ }^{2}$, Natalia Shpendik ${ }^{1}$ \\ ${ }^{1}$ Brest State Technical University, Moskovskaya 267, 224017 Brest, Belarus, e-mail: volchak@tut.by \\ ${ }^{2}$ Pomeranian University in Słupsk, Partyzantów 27, 76-200 Słupsk, Poland, e-mail: kirviel@yandex.by (corresponding author)
}

\begin{abstract}
One of the soil fertility parameters is water content in the root zone; therefore the estimation of the transformation of water resources in mineral soils of Belarus is rather relevant. The analysis of plant available moisture content (PAMC) was conducted for the topsoil layer of $50 \mathrm{~cm}$ thickness for the period of monitoring from 1960 until 2001. Results were submitted as maps on the basis of which the spatial and time variability of the PAMC was estimated. The quantitative estimation of changes in the plant available moisture content was carried out with the help of gradients of linear trends.
\end{abstract}

Key words: Belarus, mineral soils, plant available water, soil fertility

\section{Introduction}

Rational use of agro-climatic resources is a necessary part of the scientific study of measures to improve soil fertility. One of the indicators of soil fertility is the root layer humidity. However, while assessing land resources only soil fertility is taken into consideration in most cases (Alpat'ev 1969; Dębska et al. 2009; Gonet et al. 2009; Kalembasa and Becher 2009; Łabaz et al. 2011). Soil is a specific medium, and it largely reflects the atmospheric climate. Among all the elements the soil moisture balance is most complex because of its polyfactorial nature and therefore it requires special consideration (Aver'yanov 1980). Water conditions of soils and surface layer of the atmosphere is not given a high enough level of importance.

So far, there are no fundamental studies concerned with the formation rules of plant available moisture content for Belarusian mineral soil based on all data for the period of instrumental observations differentially for different soil layers. There are only limited studies of the transformation of plant available moisture content on the territory of Belarus in the context of natural and anthropogenic factors. That is why the aim of this study was to assess the spatial and temporal variations of plant available moisture content in mineral soils in Belarus. Issues related to the change forecast of plant available soil moisture content are also insufficient.

\section{Materials and methods}

Plant available moisture is used in this work to mean the humidity calculated in the study of the area moisture balance, i.e. the water available to plants contained in the soil above the permanent wilting point. Firstly, estimations of plant available moisture content (PAMC) are based on the separation of moisture available for plants from the total amount of water retained in the soil. Plant available moisture content is equally valuable for the formation of a crop that provides comparability of humidity for different geosystem types. Secondly, stocks of plant available moisture make it possible to estimate the moisture content of crops, as the moisture values of plants are comparable with the values of soil moisture, which are fluctuating within agrohydrological properties (constants). Agrohydrological constants characterize the mobility of moisture in the soil and its availability for crops, so they are physically reasonable quantitative criteria for the classification of soils by their moisture regime (Emel'anov and Maslov 1984). 
There are direct and indirect methods to determine PAMC. The indirect one is in determining the quantity of available moisture by calculating the difference between the total water content in the soil and the amount corresponding to the water content at permanent wilting point. Thus, moisture at wilting point is set to zero and is supposed to be the main agrohydrological constant. The direct laboratory-growing method supposes that soil moisture is taken into account at the moment when a grown plant with a welldeveloped root system steadily wilts due to dried up soil, and all other growth factors are at an optimum.

The amount of plant available moisture, or water content in soils, is usually expressed in millimetres of the water layer thickness. As such, it is comparable with the data on precipitation and evaporation. For accurate accounting of soil moisture available (useful) for plants, its amount is determined in a one-metre thick layer of ploughed soil. To do this, samples of the layers $0-50$ or $0-100 \mathrm{~cm}$ are taken. Soil moisture is determined in them, then multiplied by the soil weight and finally the double maximum value of hygroscopicity is subtracted (Shatkauskas 1972).

Observations of soil moisture at weather stations in Belarus were used as the main source of data in our study of the water regime and moisture. Systematic observations of soil moisture have been carried out in Belarus since 1950, at first at 13 stations of the hydrometeorological network, and now at 49 . After the analysis of primary observation materials for their completeness and duration of the observation period 44 weather stations were selected, which carry out systematic observations of mineral soil moisture (Alekseev 1975).

Figure 1 shows the soil map of Belarus and hydrometeorological network stations that were used for the study (Rogovoi 1972; Miasnikovich 2002; Smeian et al. 1977; Shatkauskas 1972).

As shown in Figure 1, soil cover is highly diverse on the territory of Belarus. This is due to the typical differences, grading of soil and parent bedrock, as well as to the humidity of the territory. Sod-podzolic, authomorphous soils and wetlands are a dominant part of the agricultural lands (72.1\%). The lowest proportion $(0.1 \%)$ is made up of sod-calcareous soils, which are the most plant available soils of the state. Authomorphous sod-podzolic soils make up 34.5\% of agricultural lands. They are developed on all parent rocks in highly diverse conditions of relief, rock formation and vegetation, and this is reflected in their appearance and features. These soils were formed in a flushing period of the water regime, which within the country has the feature of a lack of constant flow moisture with its penetration to groundwater. Thorough washing of the soil mass occurs in spring during snowmelt and partially in autumn during the rainy season. In northern and northeastern regions of the country the flushing type of water regime is more prominent (Gorbyleva et al. 2007, Kulakovskaia et al. 1974).

Sod-podzol marsh soils are formed under conditions of prolonged periodic waterlogging with surface water and groundwater, which leads to the formation of gley spots or whole gley horizons in their genetic profile. These soils are most common in the Vitebsk region, where they are formed on the rocks connected to the delayed runoff conditions. In the southern part of the country they also cover a considerable area and are confined to the vast sandy lowlands with shallow formation of groundwater.

Sod waterlogged soils are most common in the southern part of the country. Here they are formed in lowlands with shallow formation of hard groundwater. In the northern part of the country, these soils are confined to the lower slopes and small areas.

The qualitative composition of mineral soils is determined not only by their type, but also by their particle size distribution. The light- and mediumloamy soils that have a relatively stable water regime and a large supply of nutrients are the ones most suitable for agriculture (Gusev et al. 2002). Loamy soils take up $20.1 \%$ of agricultural land in the Republic. The highest proportion of these soils is in the Vitebsk region $(47.7 \%)$. The least amount of loamy soils is in the Gomel (4.1\%) and Brest (3.8\%) regions, while the proportion of sandy loam and sandy arable land is greatly increased there. In general, the arable lands in the country are dominated by sandy loam soils (45.6\%), half of which is underlain by loam and clay. Yields are significantly reduced on sandy soils, which have a more dynamic water regime in comparison with loamy ones. Sandy soils are characterized by the lowest level of productivity, and make up a fifth of the agricultural area of the Republic (21.2\%), and in the Brest and Gomel regions almost half of their area (40.8 and $46.8 \%$, respectively). The productivity of light grain texture soils increases greatly when a small depth is underlain with moraine loam or other dense rocks that contribute to plant available moisture in the upper soil profile. Sandy soils underlain by loam take up about $2 \%$ of agricultural land of the Republic. 


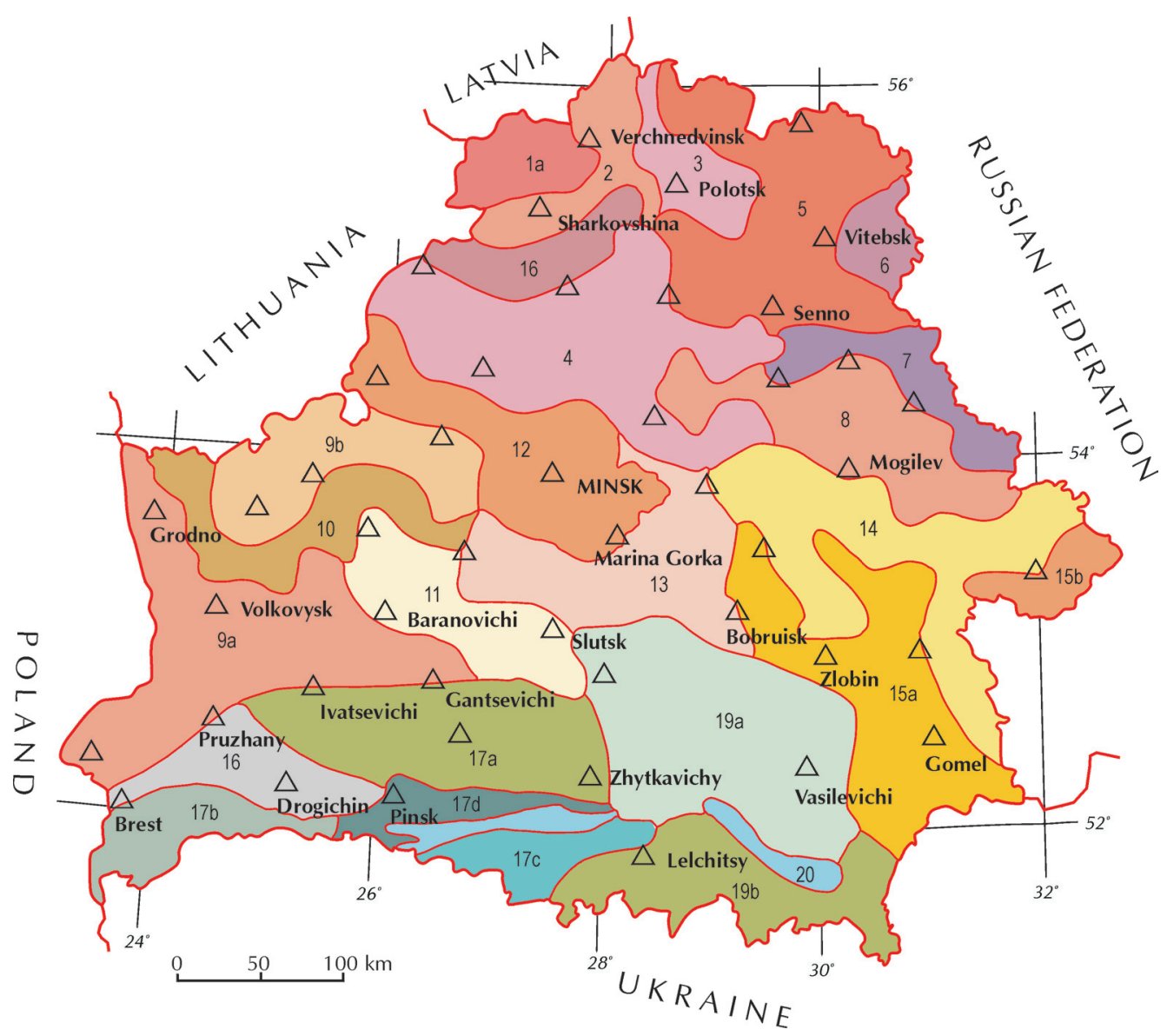

Fig. 1. Soil map of Belarus and the location of agro-meteorological stations: 1a - sod-podzolic strongly eroded loamy and sandy soils; $1 \mathrm{~b}$ - sod-podzolic loamy and sandy eroded soils, 2 - sod-podzolic loamy clay and heavily waterlogged soils, 3 - sod-podzolic silty sandy soils, 4 - sod-podzolic loamy soils, 5 - sod-podzolic loamy and sandy soils, 6 - sod-podzolic loamy and sandy soils; 7 - sod-podzolic strongly eroded silty loam soils, 8 - sod- podzolic silty loam and sandy soils; 9a - sod-podzolic loamy and sandy soils; $9 \mathrm{~b}$ - sod-podzolic loamy and sandy soils, 10 - sod-podzolic sandy soils, 11 - sod-podzolic silty loam and sandy loam soils, 12 - sod-podzolic loamy and sandy soils; 13 - sod-podzolic sandy wetlands soils, 14 - sod-podzolic loamy soils; 15a - sod-podzolic strongly waterlogged silty loam and sandy soils; 15b - sod-podzolic silty-sandy and loamy soils, 16 - sod-podzolic loamy wetlands and sandy soils; 17a - peat and sodpodzolic sandy waterlogged soil; $17 \mathrm{~b}$ - sod-podzolic sandy and swampy peat soils; 17c - sod-podzolic loamy wetlands and peat soils; 17d - sod-waterlogged soils; 18 - sod-calcareous soils; 19a - sod-podzolic sandy; 19b - sod-podzolic loamy wetlands and sandy soils, 20 - sod-podzolic silty loam and sandy loam soils. Agro-meteorological stations were marked by triangles.

The average plant available moisture content in soils during the growing season (May-August) for a soil layer $50 \mathrm{~cm}$ in thickness was used. The observational period covered the years from 1959 to 2001. However, due to the gaps in observations, the real lengths of the time series were unequal and ranged from 12 to 41 years ( 30 years on average). In some cases, we attempted to restore the missing variables by methods of simple and multiple correlation, as well as by water balance methods. In the case of a satisfactory result, the value obtained was included in the time series. The study period covers various humidification years and reflects the long-term average soil moisture conditions in Belarus.
Analysis of the initial data of plant available moisture content shows that they are highly variable. The soil is saturated with moisture to field capacity after the spring thaw, as well as after heavy rains. This water content retained in soil is considered optimal for plants.

By the middle of the growing season (JuneJuly), due to consumption of soil moisture through evapotranspiration, soil moisture content is reduced. In some periods, the moisture content may decline to discontinuity of capillary moisture and soil moisture becomes less accessible to plants and the plant starts to be oppressed and at a further reduction of moisture can be lost (Bulavko 1965; Okulik 1989; Okulik and Sudas 1981). 


\section{Results and Discussion}

The plant available moisture content of mineral soils was calculated for each region of Belarus, with the approach proposed by Pluzhnikov (Pluzhnikov et al. 1996, Pluzhnikov et al. 1995), and put together in Table 1.

Table 1. Data on average plant available moisture resources in the meter layer of mineral soils in different areas of Belarus (water content in average year)

\begin{tabular}{cccc}
\hline \multirow{2}{*}{ Area } & Area & \multicolumn{2}{c}{ Moisture content } \\
& & during the growing season \\
\cline { 2 - 4 } & {$\left[\mathrm{km}^{2}\right]$} & {$\left[\mathrm{m}^{3} \mathrm{ha}^{-1}\right]$} & {$\left[\mathrm{km}^{3}\right]$} \\
\hline Brest & 22.45 & 1030 & 2.3 \\
\hline Vitebsk & 34.30 & 1655 & 5.7 \\
\hline Gomel & 32.80 & 1363 & 4.5 \\
\hline Grodno & 22.63 & 1262 & 2.9 \\
\hline Minsk & 32.93 & 1350 & 4.4 \\
\hline Mogilev & 26.42 & 1978 & 5.2 \\
\hline Belarus & $\mathbf{1 7 1 . 5 3}$ & $\mathbf{8 6 3 8}$ & 25.0 \\
\hline
\end{tabular}

The difference in soil moisture content is caused by the texture of the soil prevailing in each region. Thus, the Brest and Grodno regions have a different moisture content while the geometrical areas of mineral lands are almost identical there. Due to the fact that the Brest region is dominated by light textured soils (for sandy soils the proportion of arable land is $46.5 \%$, and it is $37.5 \%$ for loamy ones) soil moisture content is lower than in Grodno, where there are heavier soils (sandy soils, with the proportion of arable lands of $15.2 \%$, and loamy ones $80.8 \%$ ). It is commonly known that heavy soils are able to accumulate and retain more moisture in comparison with light ones (Alibegova 1985; Gorbyleva et al. 2007).

Quantitative evaluation of changes in time series of plant available moisture content was carried out using the gradients of the linear trends. The gradient for each decade of the growing season was derived for this purpose as well as a general one for the entire growing season for the whole territory of Belarus (Table 2).

Table 2. Gradients (mm per 10 years) of plant available moisture content changes (a) and correlation coefficients of linear trendline (r) calculated for selected agro-meteorological stations

The northern part of Belarus

\begin{tabular}{|c|c|c|c|c|c|c|c|c|c|c|c|c|c|c|c|}
\hline \multicolumn{2}{|c|}{ Meteorological stations } & \multicolumn{2}{|c|}{ Verhnedvinsk } & \multicolumn{2}{|c|}{ Polock } & \multicolumn{2}{|c|}{ Sharkovshina } & \multicolumn{2}{|c|}{ Vitebsk } & \multicolumn{2}{|c|}{ Senno } & \multicolumn{2}{|c|}{ Orsha } & \multicolumn{2}{|c|}{ Gorki } \\
\hline Month & $\begin{array}{l}\text { Ten-day } \\
\text { period }\end{array}$ & a & $r$ & a & $r$ & a & $r$ & a & $r$ & a & $r$ & a & $r$ & $a$ & $r$ \\
\hline \multirow{3}{*}{ 言 } & 1 & -32.0 & -0.56 & 21.25 & 0.56 & 12.01 & 0.34 & -7.79 & -0.21 & -25.56 & -0.62 & -22.81 & -0.39 & -10.68 & -0.31 \\
\hline & 2 & -14.96 & -0.44 & 10.82 & 0.40 & 9.73 & 0.50 & 1.12 & 0.07 & -24.13 & -0.72 & -22.69 & -0.41 & 1.77 & 0.05 \\
\hline & 3 & -13.77 & -0.50 & 7.88 & 0.45 & 10.2 & 0.51 & 1.74 & 0.09 & -27.47 & -0.50 & -28.58 & -0.73 & 10.94 & 0.05 \\
\hline \multirow{3}{*}{$\stackrel{\mathrm{\pi}}{2}^{\vec{\pi}}$} & 1 & -12.97 & -0.73 & 5.06 & 0.25 & 8.46 & 0.42 & -1.96 & -0.07 & -31.86 & -0.21 & -23.58 & -0.77 & -0.68 & -0.03 \\
\hline & 2 & -20.65 & -0.64 & 3.26 & 0.13 & 4.94 & 0.24 & -2.50 & 0.06 & -25.53 & -0.63 & -21.02 & -0.93 & -4.78 & -0.18 \\
\hline & 3 & -19.41 & -0.64 & 2.04 & 0.08 & 6.02 & 0.26 & 3.58 & 0.15 & -6.91 & -0.76 & -15.39 & -0.86 & 2.34 & 0.09 \\
\hline \multirow{3}{*}{$\stackrel{\oplus}{\cong}$} & 1 & -17.49 & -0.58 & 2.91 & 0.10 & 10.05 & 0.36 & 3.46 & 0.12 & -35.43 & -0.42 & -40.34 & -0.84 & 1.10 & 0.04 \\
\hline & 2 & -19.13 & -0.55 & 5.80 & 0.18 & 13.69 & 0.48 & -0.67 & -0.02 & -44.91 & -0.63 & -51.72 & -0.83 & 1.74 & 0.06 \\
\hline & 3 & -8.92 & -0.20 & 10.57 & 0.33 & 12.44 & 0.47 & 9.72 & 0.30 & -28.56 & -0.66 & -26.63 & -0.81 & 6.45 & 0.24 \\
\hline \multirow{3}{*}{ 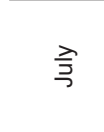 } & 1 & -12.22 & -0.34 & 5.27 & 0.17 & 16.77 & 0.52 & 3.54 & 0.14 & -35.39 & -0.70 & -29.27 & -0.55 & 0.84 & 0.03 \\
\hline & 2 & -7.74 & -0.16 & 3.62 & 0.11 & 14.66 & 0.53 & -2.00 & -0.07 & -37.27 & -0.62 & -23.79 & 0.48 & 4.23 & 0.12 \\
\hline & 3 & -5.26 & -0.12 & 3.16 & 0.09 & 15.22 & 0.50 & 6.43 & 0.17 & -11.77 & -0.16 & 6.73 & 0.32 & 4.36 & -0.01 \\
\hline \multirow{3}{*}{ 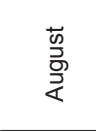 } & 1 & -13.11 & -0.29 & 5.95 & 0.14 & 13.06 & 0.42 & -5.03 & -0.14 & -25.4 & -0.30 & -17.87 & 0.58 & -0.27 & -0.01 \\
\hline & 2 & -12.43 & -0.25 & 3.90 & 0.11 & 7.57 & 0.28 & 8.45 & 0.22 & -6.53 & -0.02 & -8.09 & 0.26 & 2.46 & 0.07 \\
\hline & 3 & -8.66 & -0.20 & 1.47 & 0.04 & 15.07 & 0.46 & 5.37 & 0.14 & 3.81 & -0.59 & -2.39 & 0.71 & 5.72 & 0.16 \\
\hline \multirow{3}{*}{$\begin{array}{l}\bar{\Phi} \\
\text { है } \\
\stackrel{0}{0} \\
\stackrel{0}{0} \\
\text { के }\end{array}$} & 1 & 3.48 & 0.08 & 1.71 & 0.04 & 15.81 & 0.56 & 5.67 & 0.16 & -34.31 & 0.02 & -14.86 & 0.43 & 5.99 & 0.18 \\
\hline & 2 & 4.33 & 0.10 & 0.78 & 0.01 & 16.76 & 0.50 & 7.37 & 0.19 & -45.55 & -0.21 & -18.60 & 0.13 & 6.41 & 0.18 \\
\hline & 3 & 1.02 & 0.02 & 3.05 & 0.08 & 20.04 & 0.58 & 8.02 & 0.25 & -37.05 & -0.33 & -34.79 & -0.17 & 6.55 & 0.19 \\
\hline \multirow{3}{*}{ 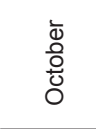 } & 1 & -0.28 & -0.01 & 1.73 & 0.05 & 20.24 & 0.60 & 5.95 & 0.18 & -31.03 & -0.02 & -19.47 & -0.11 & 9.31 & 0.27 \\
\hline & 2 & 0.06 & 0.00 & 1.08 & 0.04 & 20.74 & 0.62 & 8.31 & 0.26 & -22.38 & -0.16 & -10.85 & -0.17 & 5.23 & 0.18 \\
\hline & 3 & -4.03 & -0.11 & 0.36 & 0.01 & 15.49 & 0.47 & 6.75 & 0.22 & -19.65 & -0.07 & -14.03 & -0.2 & 5.06 & 0.17 \\
\hline \multicolumn{2}{|c|}{ Vegetation period } & -1.22 & -0.43 & 4.56 & 0.19 & 11.16 & 0.59 & 4.46 & 0.26 & -21.62 & -0.71 & -17.65 & -0.62 & 2.23 & 0.11 \\
\hline
\end{tabular}

Note: Statistically significant values are marked in bold 
The southern part of Belarus

\begin{tabular}{|c|c|c|c|c|c|c|c|c|c|c|c|c|c|c|c|c|c|c|c|}
\hline \multirow{2}{*}{\multicolumn{2}{|c|}{$\begin{array}{c}\begin{array}{c}\text { Meteorological } \\
\text { stations }\end{array} \\
\text { Month } \begin{array}{c}\text { Ten-day } \\
\text { period }\end{array}\end{array}$}} & \multicolumn{2}{|c|}{ Globin } & \multicolumn{2}{|c|}{ Prugany } & \multicolumn{2}{|c|}{ Vysokoe } & \multicolumn{2}{|c|}{ Gomel } & \multicolumn{2}{|c|}{ Polesskaj } & \multicolumn{2}{|c|}{ Vaselevichi } & \multicolumn{2}{|c|}{ Brest } & \multicolumn{2}{|c|}{ Pinsk } & \multicolumn{2}{|c|}{ Lelchicy } \\
\hline & & a & $r$ & a & $r$ & a & $r$ & a & $r$ & a & $r$ & a & $r$ & a & $r$ & a & $r$ & a & $r$ \\
\hline \multirow{3}{*}{$\overline{\bar{z}}$} & 1 & 15.56 & 0.58 & -26.67 & -0.03 & 7.52 & 0.32 & 1.21 & 0.43 & 17.92 & 0.54 & -8.39 & -0.39 & 4.92 & 0.29 & 3.50 & 0.21 & 9.05 & 0.37 \\
\hline & 2 & 13.97 & 0.59 & -0.56 & -0.13 & 9.42 & 0.38 & 7.06 & 0.20 & 12.06 & 0.62 & -6.57 & -0.35 & -1.29 & -0.07 & 7.06 & -0.02 & 6.88 & 0.33 \\
\hline & 3 & 11.44 & 0.49 & -2.06 & 0.20 & 11.75 & 0.52 & 4.81 & 0.18 & 15.75 & 0.63 & -5.36 & -0.30 & -2.35 & -0.14 & -0.54 & -0.05 & 6.50 & 0.33 \\
\hline \multirow{3}{*}{$\stackrel{\vec{\pi}}{\sum}$} & 1 & 12.78 & 0.61 & 23.81 & -0.11 & 7.96 & 0.38 & -3.26 & -0.14 & 15.98 & 0.34 & -4.96 & -0.26 & -1.18 & -0.09 & -1.01 & -0.10 & 5.56 & 0.31 \\
\hline & 2 & 11.76 & 0.55 & -1.74 & 0.03 & 6.71 & 0.31 & 5.32 & 0.23 & 12.39 & 0.30 & -2.10 & -0.10 & -1.5 & -0.10 & -1.92 & -0.07 & 7.13 & 0.36 \\
\hline & 3 & 8.95 & 0.40 & 0.47 & 0.10 & 7.11 & 0.28 & 1.74 & 0.06 & 11.33 & 0.28 & 2.10 & 0.12 & -2.93 & -0.17 & -1.47 & 0.18 & 6.54 & 0.34 \\
\hline \multirow{3}{*}{ 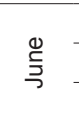 } & 1 & 7.53 & 0.28 & 1.89 & -0.09 & 6.71 & 0.27 & -0.36 & -0.01 & 14.34 & 0.43 & -4.83 & -0.28 & 0.64 & 0.04 & 4.14 & 0.14 & 6.80 & 0.37 \\
\hline & 2 & 10.79 & 0.46 & -1.79 & -0.08 & 3.35 & 0.13 & 6.29 & 0.26 & 12.58 & 0.32 & 2.22 & 0.12 & 3.40 & 0.17 & 3.62 & 0.04 & 8.18 & 0.38 \\
\hline & 3 & 11.56 & 0.49 & -1.81 & -0.04 & 12.2 & 0.44 & 8.59 & 0.35 & 17.47 & 0.46 & 6.89 & 0.34 & 5.79 & 0.31 & 1.36 & 0.18 & 9.25 & 0.51 \\
\hline \multirow{3}{*}{ 产 } & 1 & 5.53 & 0.22 & -0.91 & 0.01 & 5.62 & 0.21 & -0.99 & -0.04 & 14.05 & 0.37 & 5.63 & 0.25 & 9.36 & 0.44 & 5.92 & 0.18 & 9.12 & 0.48 \\
\hline & 2 & 7.64 & 0.27 & 0.17 & -0.04 & 6.36 & 0.23 & -0.46 & -0.01 & 17.4 & 0.46 & 5.61 & 0.27 & 8.03 & 0.39 & 5.61 & 0.17 & 13.37 & 0.53 \\
\hline & 3 & 5.79 & 0.20 & -1.05 & 0.09 & 8.62 & 0.28 & -1.04 & -0.05 & 2.05 & 0.54 & 3.65 & 0.20 & 5.45 & 0.23 & 6.41 & 0.13 & 15.79 & 0.66 \\
\hline \multirow{3}{*}{$\begin{array}{l}\frac{0}{3} \\
\frac{3}{3}\end{array}$} & 1 & 7.13 & 0.26 & 2.54 & -0.22 & 6.39 & 0.25 & 4.05 & 0.13 & 17.89 & 0.44 & 0.01 & 0.00 & -0.28 & -0.01 & 5.10 & -0.03 & 12.14 & 0.49 \\
\hline & 2 & 6.72 & 0.27 & -5.33 & -0.10 & 12.84 & 0.47 & 1.78 & 0.45 & 17.84 & 0.42 & 0.30 & 0.01 & -0.25 & -0.01 & $\begin{array}{l}-1.02 \\
\end{array}$ & -0.04 & 12.4 & 0.53 \\
\hline & 3 & 2.26 & 0.09 & -2.36 & -0.06 & 11.96 & 0.42 & 1.36 & 0.45 & 12.72 & 0.35 & 4.24 & 0.28 & 0.81 & 0.03 & -1.09 & -0.08 & 2.73 & 0.15 \\
\hline \multirow{3}{*}{$\begin{array}{l}\bar{\Phi} \\
\stackrel{0}{E} \\
\frac{1}{\Phi} \\
\stackrel{0}{0} \\
\infty\end{array}$} & 1 & 3.23 & 0.14 & -1.33 & -0.06 & 11.98 & 0.40 & 10.64 & 0.33 & 18.17 & 0.43 & 6.68 & 0.30 & 5.39 & 0.21 & -2.00 & 0.14 & 2.34 & 0.12 \\
\hline & 2 & 3.44 & 0.15 & -3.76 & 0.28 & 15.37 & 0.48 & 15.1 & 0.40 & 21.47 & 0.45 & 6.07 & 0.26 & 4.48 & 0.20 & 3.56 & 0.19 & 8.95 & 0.39 \\
\hline & 3 & 6.08 & 0.29 & 6.40 & 0.00 & 11.27 & 0.40 & 7.21 & 0.22 & 19.73 & 0.41 & 0.54 & 0.02 & 0.75 & 0.04 & 6.20 & 0.28 & 7.72 & 0.45 \\
\hline \multirow{3}{*}{$\begin{array}{l}\bar{\Phi} \\
\stackrel{0}{0} \\
\text { Oँ }\end{array}$} & 1 & 7.57 & 0.47 & 0.02 & -0.14 & 9.03 & 0.30 & 7.83 & 0.27 & 16.84 & 0.57 & 3.97 & 0.22 & -0.30 & -0.01 & 9.39 & -0.09 & 8.3 & 0.43 \\
\hline & 2 & 9.21 & 0.63 & -3.08 & -0.22 & 4.35 & 0.18 & 13.76 & 0.45 & 17.69 & 0.46 & 3.83 & 0.26 & -0.36 & -0.02 & -2.89 & 0.08 & 5.72 & 0.22 \\
\hline & 3 & 4.49 & 0.22 & -4.29 & -0.26 & 4.86 & 0.23 & 10.66 & 0.47 & 17.68 & 0.54 & -0.12 & -0.01 & 1.50 & 0.09 & 2.40 & 0.01 & 7.53 & 0.36 \\
\hline \multicolumn{2}{|c|}{$\begin{array}{l}\text { Vegetation } \\
\text { period }\end{array}$} & 7.88 & 0.46 & -0.16 & -0.01 & 8.16 & 0.48 & 3.71 & 0.20 & 15.32 & 0.45 & 3.47 & 0.25 & 2.87 & 0.25 & 1.43 & 0.06 & 8.21 & 0.53 \\
\hline
\end{tabular}

Note: Statistically significant values are marked in bold

The central part of Belarus

\begin{tabular}{|c|c|c|c|c|c|c|c|c|c|c|c|c|c|c|c|}
\hline \multicolumn{2}{|c|}{ Meteorological stations } & \multicolumn{2}{|c|}{ Minsk } & \multicolumn{2}{|c|}{ Marina-Gorka } & \multicolumn{2}{|c|}{ Grodno } & \multicolumn{2}{|c|}{ Volkovysk } & \multicolumn{2}{|c|}{ Kostukovichi } & \multicolumn{2}{|c|}{ Baranavichi } & \multicolumn{2}{|c|}{ Bobruisk } \\
\hline Month & $\begin{array}{l}\text { Ten-day } \\
\text { period }\end{array}$ & a & $r$ & a & $r$ & a & $r$ & a & $r$ & a & $r$ & a & $r$ & a & $r$ \\
\hline \multirow{3}{*}{ 홍 } & 1 & -17.31 & -0.68 & 12.13 & 0.49 & 3.05 & 0.13 & 21.3 & 0.66 & 16.49 & 0.45 & 22.35 & 0.55 & 14.51 & 0.51 \\
\hline & 2 & -4.83 & -0.24 & 11.11 & 0.53 & -3.74 & -0.20 & 19.62 & 0.61 & 7.98 & 0.30 & 14.74 & 0.46 & 18.90 & 0.60 \\
\hline & 3 & -6.40 & -0.28 & 14.25 & 0.67 & -4.60 & -0.31 & 13.42 & 0.47 & 22.84 & 0.49 & 12.19 & 0.43 & 14.68 & 0.65 \\
\hline \multirow{3}{*}{$\sum^{\frac{\pi}{2}}$} & 1 & -6.20 & -0.34 & 7.36 & 0.34 & -3.46 & -0.20 & 8.31 & 0.35 & 16.56 & 0.46 & 12.15 & 0.38 & 14.44 & 0.63 \\
\hline & 2 & -7.96 & -0.40 & 6.02 & 0.30 & -0.81 & -0.05 & 6.42 & 0.23 & 16.42 & 0.40 & -0.37 & -0.01 & 14.41 & 0.65 \\
\hline & 3 & -4.29 & -0.16 & 9.03 & 0.38 & 2.10 & 0.11 & 8.82 & 0.29 & 9.44 & 0.35 & -0.43 & -0.01 & 11.15 & 0.50 \\
\hline \multirow{3}{*}{$\stackrel{0}{5}$} & 1 & -4.11 & -0.16 & 6.39 & 0.24 & 2.34 & 0.11 & 10.55 & 0.33 & 6.33 & 0.23 & 8.66 & 0.27 & 15.96 & 0.65 \\
\hline & 2 & -4.64 & -0.17 & 7.35 & 0.30 & 5.49 & 0.26 & 10.05 & 0.34 & 1.96 & 0.06 & 8.09 & 0.23 & 19.64 & 0.74 \\
\hline & 3 & 4.22 & 0.12 & 12.93 & 0.55 & 7.20 & 0.43 & 11.54 & 0.34 & 10.62 & 0.30 & 18.35 & 0.45 & 21.03 & 0.76 \\
\hline \multirow{3}{*}{ 亮 } & 1 & -3.04 & -0.09 & 13.25 & 0.55 & 7.40 & 0.35 & 9.72 & 0.28 & 6.92 & 0.18 & 13.44 & 0.44 & 14.52 & 0.63 \\
\hline & 2 & -2.00 & -0.06 & 9.76 & 0.40 & 9.64 & 0.43 & 17.02 & 0.48 & 17.25 & 0.32 & 11.82 & 0.35 & 14.67 & 0.55 \\
\hline & 3 & 4.89 & 0.12 & 11.07 & 0.44 & 9.75 & 0.34 & 14.13 & 0.41 & 18.14 & 0.33 & 24.07 & 0.60 & 12.96 & 0.51 \\
\hline \multirow{3}{*}{$\begin{array}{l}\vec{n} \\
\frac{0}{2} \\
\frac{0}{2}\end{array}$} & 1 & -9.99 & -0.28 & 5.63 & 0.23 & 11.28 & 0.40 & 14.96 & 0.41 & 13.77 & 0.32 & 19.94 & 0.48 & 12.74 & 0.52 \\
\hline & 2 & -5.42 & -0.15 & 3.33 & 0.14 & 11.41 & 0.42 & 14.96 & 0.45 & 20.78 & 0.44 & 10.94 & 0.31 & 6.67 & 0.28 \\
\hline & 3 & -6.76 & -0.20 & 2.99 & 0.11 & 1.90 & 0.06 & 4.64 & 0.15 & 24.37 & 0.50 & 17.77 & 0.46 & 8.57 & 0.37 \\
\hline \multirow{3}{*}{$\begin{array}{l}\bar{\Phi} \\
\text { है } \\
\Phi \\
\stackrel{0}{0} \\
\stackrel{0}{0} \\
\infty\end{array}$} & 1 & 0.03 & 0.00 & 12.05 & 0.46 & 7.23 & 0.25 & 4.09 & 0.03 & 23.42 & 0.64 & 19.33 & 0.48 & 10.82 & 0.48 \\
\hline & 2 & 3.62 & 0.09 & 14.68 & 0.52 & 5.24 & 0.16 & 15.27 & 0.41 & 21.94 & 0.59 & 28.49 & 0.62 & 10.14 & 0.49 \\
\hline & 3 & 4.15 & -0.12 & 11.74 & 0.47 & 7.70 & 0.28 & 15.75 & 0.44 & 18.32 & 0.49 & 19.03 & 0.47 & 11.99 & 0.58 \\
\hline \multirow{3}{*}{ 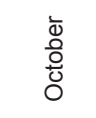 } & 1 & -1.75 & -0.05 & 11.14 & 0.43 & 8.36 & 0.30 & 11.97 & 0.42 & 17.36 & 0.45 & 11.85 & 0.35 & 9.75 & 0.46 \\
\hline & 2 & -9.80 & -0.26 & 9.11 & 0.43 & 7.07 & 0.27 & 10.71 & 0.38 & 23.42 & 0.56 & 8.25 & 0.17 & 10.14 & 0.49 \\
\hline & 3 & -7.90 & -0.24 & 12.46 & 0.61 & 6.91 & 0.28 & 12.43 & 0.46 & 17.14 & 0.60 & 7.63 & 0.25 & 8.40 & 0.43 \\
\hline Veg & oeriod & -4.93 & -0.25 & 8.78 & 0.46 & 7.23 & 0.45 & 9.99 & 0.41 & 15.48 & 0.44 & 13.04 & 0.59 & 13.47 & 0.70 \\
\hline
\end{tabular}

Note: Statistically significant values are marked in bold 
The results showed that in most stations there is a prevailing trend to increase plant available moisture content in general during the growing season. This pattern is similar for inner-growing seasons, with the exception of data from the Verhnedvinsk weather station. The tendency to increase is probably due to a decrease in evapotranspiration, which in its turn is caused by a significant decrease in wind speed. In addition, there was an increased precipitation in the northern part of Belarus. Plant available moisture content having a negative trend during the growing season is observed at the Verhnedvinsk station in the majority of decades in the warm period, and the same trend can be seen at Senno and Orsha stations. Positive trends are observed at the stations of Sharkovshina, Marina-Gorka, Grodno, Volkovysk, Kostyukovichi, Baranovichi, Bobruisk, Zhlobin, Vysokoe, Poleskaya and Lelchitsy. They stand out most clearly in the third decade of June, when there is the highest number of stations with positive gradient changes in plant available moisture content in the $50 \mathrm{~cm}$ layer of mineral soils.

Natural conditions for agricultural activities in Belarus are extremely complex and varied. However, in recent years it has become increasingly urgent to adapt agriculture to specific landscape conditions in order to reduce agricultural production costs. Adapting agriculture to specific landscape conditions should be based on a diligent accounting of natural environmental conditions of specific areas, regions, individual land users and the allocation of territories with homogeneous conditions for agriculture. The latter is achieved through the soil-ecological, soil-geographical and natural reclamation zoning, which typically takes into account not only soil conditions, but other natural and anthropogenic factors that affect crop yields and production efficiency. In this research areas with homogeneous variability of moisture content were identified, i.e. agrohydrological zoning of Belarus was performed on plant available moisture content change in the $50 \mathrm{~cm}$ layer (Fig. 2) and $100 \mathrm{~cm}$ layer of mineral soils (this is presented in the article by Volchek and Shpendik 2006). Average deviations of plant available moisture content gradient display changes of $14 \%$ among districts, although in some cases they are as high as $30 \%$. The resulting errors are not beyond the permissible quantity representations for elements of water balance.

As shown in Fig. 2, changes in the plant available moisture content have a complex time pattern, indicating that the changes in plant available moisture content are multifactorial. Analysis of moisture in Belarus has identified three areas with characteristic changes. First, there is an area with a positive trend of plant available moisture content for the growing season. Second, there is an area with a negative trend. Third, there is an area where significant trends in changes of plant available moisture content were not revealed. In southern Belarus there are zones with increasing plant available water supplies and areas where moisture content remains constant. In the northern and central part of Belarus water supplies display a more differential character of changes, which is associated with a wide variety of soil and climate change resources. Here parent rocks are hard loamy, loamy and silty loam soils, as well as forests and forestlike loam. In recent years there has been an increase in the spatial heterogeneity of atmospheric precipitations. There are areas of increasing rainfall (Vitebsk region, as well as Zhitkovichi and Lelchitsa districts) and a reduction zone (south- eastern part of Belarus).

The time course of evapotranspiration fluctuations also has its changes. Since the late 1990s there has been a tendency to reduce evapotranspiration at meteorological stations of Vasilevichi, Polesskaya and Sharkovshina, while Valkavysk meteorological station has shown some increase in evapotranspiration. There have also been changes in wind speed. In the early $70 \mathrm{~s}$ there was a sharp decrease in wind speed, followed by a stabilization process. Stronger wind speed reduction occurred in the middle of the 90s. The greatest changes in wind speed occurred in the central part of Belarus (Minsk and Narach weather stations). The speed is reducing more quickly in Polotsk lowland in comparison with Polessie. In addition, attention is drawn to the axis connecting the Polesskaya and Valkavysk weather stations, where wind speed tends to increase. All this influenced the trends of plant available moisture content.

Evaluated zones have a longitudinal distribution pattern on the territory of Belarus, which is due to the fact that the formation process of plant available moisture content for a half-metre layer of soil is mainly influenced by climatic factors, and they are known to have a latitudinal distribution pattern. When forming plant available moisture content in a metre layer hydrogeological and geological conditions play an important role in addition to climatic factors, and that contributes to the spatial structure of the longitudinal zoning character. 


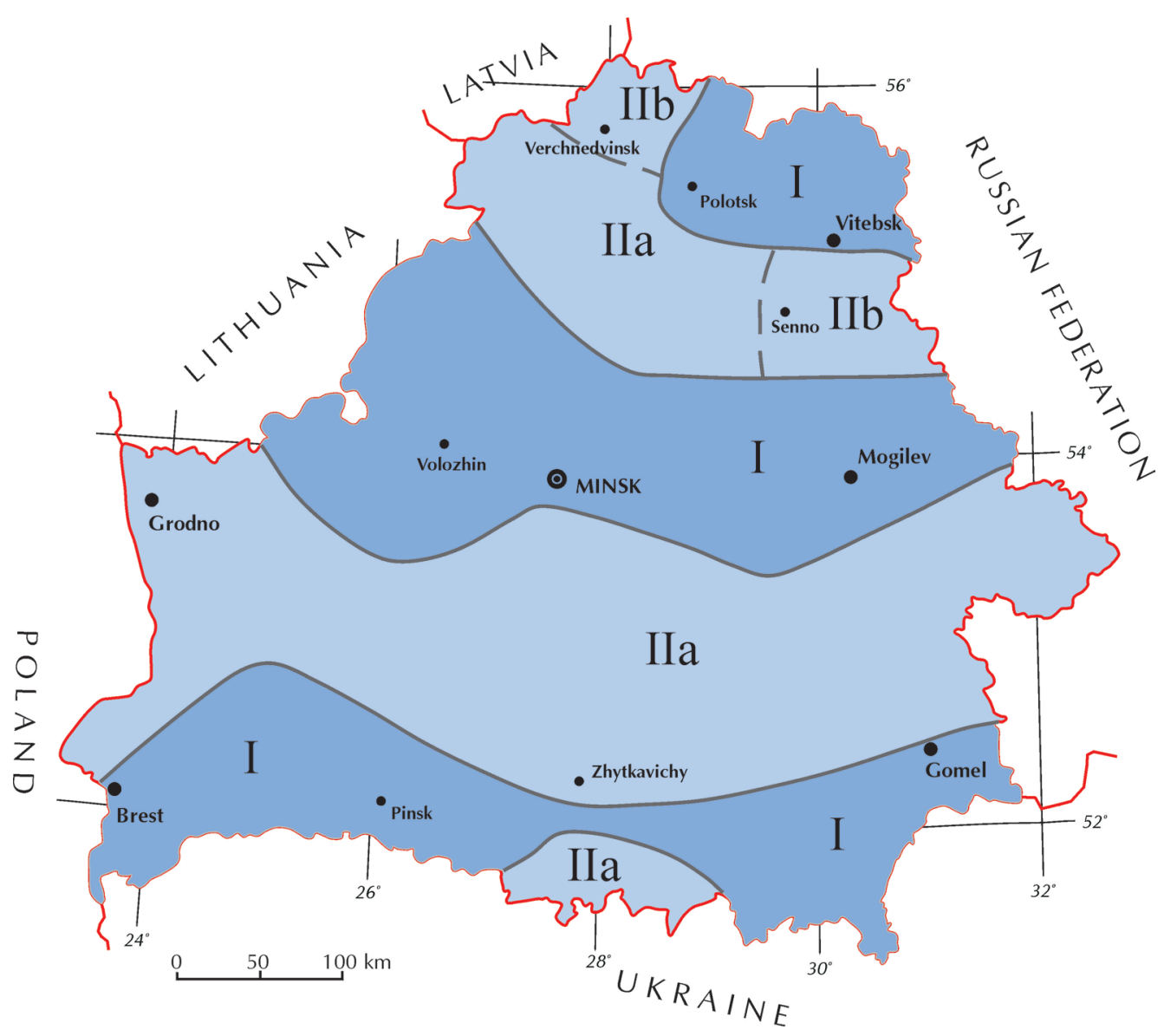

Fig. 2. Agrohydrological zonation of Belarus according to patterns of transformation dynamics of plant available water content in soils: I - area with a relatively constant moisture content; IIa - area with increasing plant available moisture content; IIb - area with decreasing plant available moisture content

\section{Conclusions}

Comprehensive analysis of the time series of plant available moisture content has yielded the following new results:

1. Current moisture content of mineral soils was calculated for each region of Belarus. Maximum moisture content is in the Mogilev Region $\left(1978 \mathrm{~m}^{3} \mathrm{ha}^{-1}\right)$, while minimum ones are in the Brest region $\left(1030 \mathrm{~m}^{3}\right.$ $\left.\mathrm{ha}^{-1}\right)$.

2. The transformation regularities of plant available moisture content are established for the geosystems of Belarus. Reducing plant available moisture content in a half-metre layer of sod-podzolic loamy soil during the growing season is typical for the Verkhnedvinsk area in the warm period for the majority of decades, and the same trend is observed at Sianno and Orsha meteorological stations. Positive trends are observed at the stations of Sharkovshchina,
Marina-Gorka, Grodno, Volkovysk, Kostyukovich, Baranovichi, Bobruisk, Zhlobin, Vysokoe, Polessie and Lelchitsy. They stand out most clearly in the third week of June, when there is the largest number of districts with the positive gradient of plant available moisture content change for $50 \mathrm{~cm}$ of the mineral soil layer.

For the metre layer an increase in plant available moisture content is typical only for sod-podzolic soils in Bobruisk, Baranovichi, Marina Gorka, Polessie, Lelchytsy and Sharkovshchina. A negative trend is observed in Verkhnedvinsk. In the other studied areas the metre layer reveals no trends.

3. According to observed long-term changes in soil moisture content the agrohydrological zoning of Belarus territory was carried out. Three areas were designated according to changes in plant available moisture content: I - area with relatively constant moisture content; II - areas where plant available water supplies increase; III - areas where plant available 
water supplies reduce. In southern Belarus a zone with increasing plant available water supplies was designated, as well as an area where moisture content remains constant. In the northern and central part of Belarus water supplies have a differential character of changes, which is associated with the wide variety of the soil cover. The resulting trends of plant available moisture content in light-textured soils are associated with changes in precipitation, wind and evaporation.

\section{References}

Alekseev G.A., 1975, Metody ocenki sluchainykh pogreshnostei gidrometeorologicheskoi informacii (Methods of assessment of random errors of hydrometeorological information), Gidrometeoizdat, Leningrad, p. 95 (in Russian).

Alibegova J.D., 1985, Prostranstvenno-vremennaia struktura polei zhidkikh osadkov (Spatial and temporal structure of rainfall fields), Gidrometeoizdat, Leningrad, p. 229 (in Russian).

Alpat'ev A.M., 1969, Vlagooboroty v prirode i ikh preobrazovania (Hydrologic cycle in nature and their conversion), Gidrometeoizdat, Leningrad, p. 323. (in Russian).

Aver'yanov A.P., 1980, Vozmozhnosti prognozirovania zapasov vlagi v pochve po vlazhnosti verkhnikh pochvennych gorizontov (Possibility of predicting soil moisture humidity upper soil horizons), Tr. MGMI 67: 81-94 (in Russian).

Bulavko A.G., 1965, Kompleksnyi pokazatel urovnia vlagozapasov v rechnykh vodosborakh (Comprehensive indicator of the level of moisture content in catchments), Proc. of the Conference on the experimental study of flow and water balance of river basins, Valdai: 48-54 (in Russian).

Dębska B., Szombathová N., Banach-Szott M., 2009, Properties of humic acids of soil under different management regimes, Pol. J. Soil Sci. 42(2): 131-138.

Emel'anov V.A., Maslov V.P., 1984, Issledovania raspredelenii vlagozapasov po profiliu oroshaemykh pochv (Investigation of the distribution of moisture content in the profile of irrigated soils), Pochvovedenie 10: 108-112 (in Russian).

Gonet S.S., Dębska B., Dziamski A., Banach-Szott M., Zaujec A., Szombathová N., 2009, Properties of organic matter in Haplic Luvisol under arable, meadow and forest management, Pol. J. Soil Sci. 42(2): 139-148.

Gorbyleva A.I., Vorobev V.B., Komarov M.M., Minchenko T.E., Petrovskii E.I., Poddubnyi O.A., 2007, Pochvy Belarusi: uchebnik posobie dla studentov agronomicheskich specialnostej uchregdenij, obespechivauschich poluchenie vysshego obrazovania (Soils of Belarus: Textbook for students of agronomy institutions providing higher education), Minfina, Minsk, p. 183 (in Belarusian).
Gusev E.M., Nasonova O.N., Busarova O.E., 2002, Uchet prostrsnstvennoi izmenchivosti territorii pri modelirovanii dinamiki vlagozapasov i summarnogo isparenia dla raionov stepnoi i lesostepnoi zon (The inclusion of spatial variability territory for modelling the dynamics of moisture content and evapotranspiration for the areas of the steppe and forest-steppe zones), Vodnye Resursy 29(1): 107-119 (in Russian).

Kalembasa D., Becher M., 2009, Properties of organic matter in chosen soils fertilized with sewage sludge, Environ. Protect. Eng. 35(2): 165-171.

Kulakovskaia T.N., Rogovoi P.P., Smeian N.I. (eds), 1974, Pochvy Belorusskoj SSR (Soils of the Byelorussian SSR), Uradzhai, Minsk p. 328 (in Belarusian).

Łabaz B., Glina B., Bogacz A., 2011, Properties of humus substances in differently used soils of the Milicz-Głogów depression, Pol. J. Soil Sci. 44(2): 177-192.

Miasnikovich M.V. (ed.), 2002, Natsyianalny Atlas Belarusi: Gleby i ziamelnya resursy (National Atlas of Belarus: Soils and land resources), Belkartografia, Minsk: 98-111 (in Belarusian).

Okulik N.V., 1989, Vodnyj regim i produktivnost pochv (Water conditions and soil productivity), Uradzhai, Minsk, p. 191 (in Belarusian).

Okulik N.V., Sudas A.S., 1981, Transformacia vodno-teplovogo rezhima $\mathrm{v}$ rastitelnom pokrove osushennykh torfianykh pochv (Transformation of hydrothermal regime in the vegetation of drained peat soils), Tr. Bel. Research Institute of Land Reclamation and Water Resources, Minsk: 57-64 (in Belarusian)

Pluzhnikov V.N., Cherepansky M.M., Makarevich A.A., 1995, Vodnye resursy Respubliki Belarus (Water Resources of the Republic of Belarus), The results of implementation of individual projects in the field of rational use and protection of water resources of the Republic of Belarus: Tr. TsNIIKIVR, Minsk: 18-24 (in Belarusian).

Pluzhnikov V.N., Fadeev M.V., Buchurin V.I., 1996, Vodnye resursy Belarusi, ich ispolzovanie i ochrana (Water resources in Belarus, their use and protection), Prirodnye Resursy 1: 24-29 (in Russian).

Rogovoi P.P., 1972, Vodnyj rezhim pochvogruntov na territorii Belarusi (Soil water regime on the territory of Belarus), Izd. Nauka Tekhnika, Minsk, p. 303 (in Russian).

Shatkauskas G.I., 1972, Optimalnye glubiny vziatia prob pri opredelenii vlazhnosti pochv vesovym metodom (Optimal depth of sampling in determining soil moisture gravimetrically), Voprosy Melioratsii 7(15): 12-16.

Smeian N.I., Ivaniuk V.V., Skripskii A.G., 1977, Agrogidrologicheskie svoistva pochv Belorusskoi SSR (Agrohydrological properties of the soils of the Byelorussian SSR), Minsk 333 (in Belarusian).

Volchek A., Shpendik N., 2006, Transformacia vlagozapasov mineralnych pochv (Transformation of the water supplies of mineral soils), Book of abstracts of the 3rd International Workshop "Regional problems of ecology: toward a solution", Polotsk: 132-133 (in Belarusian). 